\title{
THE LAW OF FOREST IN INDONESIA: PREVENTION AND SUPPRESSION OF FOREST FIRES
}

\author{
Ariawan Gunadia, Gunardib, Martono ${ }^{c}$
}

\begin{abstract}
$\mathrm{F}$ orests have significant function related biological diversity, habitat protection of flora fauna such as F orangutan, tiger, elephant; climate-related functions such as carbon sequestration, air pollution; human settlements, human health, school activities, habitat for people, rural livelihoods; state defense as natural resources such as commercial industrial wood, non-wood forest products, international and national trade; ecotourism, and recreation. However the problem in Indonesia is forest fires. In order to maintain its functions, all the famers, forestry-concession owners, government, local government and private enterprise should prevent and suppress the forest fires through the existing law and regulations such as Constitution Law of 1945, Act Number 5 Year 1990, Act Number 22 Year 1999, Act Number 41 Year 1999, Act Number 1 Year 2009, Act Number 6 Year 1994 and Act Number 17 Year 2004 and aircraft operation conducted by foreign aircraft such as Australia, Canada, Malaysia, Russia and Singapore to assist Indonesian's forest fires.
\end{abstract}

Keywords: aircraft operation; forest fires; legal ground; liability; responsibility.

\section{INTRODUCTION}

$\mathrm{I}^{\mathrm{n}}$

ndonesia is the world's largest archipelago's State. It is consisting of 17,508 Islands, about

6,000 of which are inhibited, the population was 267 million. Global climate change has impact to contribute to the greenhouse gas (GHG) pollutant in terms of carbon emission. ${ }^{1}$ In addition to, an Indonesian forest fires have created an ecological disaster, economic losses, 8,063 square miles of land burned, health problems, health impact, 21 deaths, more than half a million people suffering respiratory problems and international trade as well. The World Bank (WB) estimates that Indonesia's economy has lost US\$16 billion due to the forest fires. There are total of 56 companies were involved in the land-clearing activities that led to the fires. Mostly pulp wood and palm oil plantations operating on Sumatra and Kalimantan Island. ${ }^{2}$

\footnotetext{
a Fakultas Hukum Universitas Tarumanagara, Jalan Letjen S. Parman St Nomor 1, Jakarta 11440, email: ariawangun@gmail.com.

b Fakultas Hukum Universitas Tarumanagara, Jalan Letjen S. Parman St Nomor 1, Jakarta 11440, email: gunardi@fh.untar.ac.id.

c Fakultas Hukum Universitas Tarumanagara, Jalan Letjen S. Parman St Nomor 1, Jakarta 11440, email: martono@fh.untar.ac.id.

1 Gunardi, Ronnie and K.Martono, Legal Aspects, Economic and Aircraft's Water Bombing Related to Forest Fires in Indonesia.www.ijbmi.org, Vol. 6 (3) March 2017.
}

2 The Jakarta Post., Indonesia Punishes 23 Companies for Causing Forest Fires. https://www.thejakartapost.com/news/2015/12/23/indonesia-punishes-23-companies-causing-forestfires.html. December 23, 2015.Accessed on 19 May 2019. 
Forest as national development capital, provides actual benefits for the life and live-hood of Indonesian nation, either ecological, social-cultural, or economic benefits, in balance and dynamic manner. Therefore, forests must be administered and managed, preserved and utilized incessantly for the welfare of Indonesian society, both the present and future generation in line with Article 33 of the 1945 Constitution as the constitutional basis setting forth that earth, water and natural resources contained therein shall be controlled by the State and used for people's maximum welfare, forestry management shall always contain spirit of democracy, be equitable and sustainable. Therefore, forestry management must be conducted with the principles of benefit and sustainability, democracy, justice, togetherness, transparency and unity based on noble morality and responsibility. ${ }^{3}$ This article purporsed to solve the problem of forest fires through the existing law, regulations and aircraft operation conducted the foreign as well as domestic aircraft in order to the existing forest maintain its functions. All institution such government, local government, farmers and forestry-concession owner should support to prevent and suppress the forest fires.

\section{RESEARCH METHOD}

$\mathrm{T}$ he normative juridical approach with normative law research mapping is used in this study. This will examine and analyze the legal materials and legal issues related to environment especially with regard to prevention and suppression of forest fires in Indonesia. It is expected that the results will be able to clarify the problems of this study. Sources of legal materials used in the study consist of legal material $1^{\text {st }}, 2^{\text {nd }}$ and $3^{\text {rd }}$ as well as the first legal material that is authoritative, which mean that the material is governed by the 1945 Constitution of the Republic of Indonesia, Act Number 5 Year 1990,4 Act Number 22 Year 1999,,$^{4}$ Act Number 41 Year 1999,6 Law Number 1 Year 2009,7 including its implementing regulation, Act Number 6 Year 1994, ${ }^{8}$ Act No.17 Year 2004, ${ }^{9}$ and Presidential Regulation Number 46 Year 2008, ${ }^{10}$ whilst

\footnotetext{
3 Act concerning Forestry, Act No.41 Year 1999, State Gazette of the Republic of Indonesia No.167 Year 1999 , Supplement State Gazette of the Republic of Indonesian No. 3888.

4 Act Concerning Conservation of Living Resources and Their Ecosystems, Act.No.5 Year 1990, State Gazette of the Republic of Indonesia Number 49 Year 1990, Supplement State Gazette of the Republic of Indonesia Number 3419)

5 Act Concerning Regional Administrations, Act No.22 Year 1999, State Gazette of the Republic of Indonesian Number..., Supplement State Gazette of the Republic of Indonesian No....

6 Act Concerning Forestry, Act No.41 Year 1999, State Gazette of the Republic of Indonesia Number 167, Supplement of State Gazette of the Republic of Indonesia Number 3888.

7 Act Concerning Civil Aviation, Act No.1 Year 2009, State Gazette of the Republic of Indonesia No.1 Year 2009, Supplement State Gazette of the Republic of Indonesia No.4956.

8 Act Concerning ratification of the United Nations Framework Convention on Climate Change (UNFCCC), Act No.6 Year 1994.

9 http://unfccc.int/Kyoto_protocol/status_of_ratification/items/2613.php(down load on 1 November 2016.

10 Presidential Regulation Concerning National Council for Climate Change, (Pres.Reg.No.46 Year 2008) [4 July 2008].
} 
the $2^{\text {nd }}$ legal material related to the publication of laws and regulations that is not an official pitch but still related, such as text books, theses and dissertations law material law the $3^{\text {rd }}$ one is a legal dictionary, an additional statement on the court decision and also the opinion of legal experts published in journals, magazines or other sources. ${ }^{11}$

\section{DISCUSSION}

\section{Source of the Haze}

$\mathrm{T}$ he fires are caused by firms and farmers engaging in illegal slash-and-burn practices as a relatively inexpensive means to clear their land of unwanted vegetation and peat. Sumatra and Kalimantan possess large areas of peat-land, which is highly combustible during dry season. Forest fires become a problem every year during the annual dry season, when fires are lit to clear and/or prepare land for agriculture. The smoke from the fires creates "haze" in Indonesia. Fires occur throughout Indonesia and on all types of soils, but fires on peat-lands are of particular concern as they cause up to $90 \%$ of the haze. Peat-lands are concentrated in lowland areas of Sumatra, Kalimantan and Papua, where the worst impacts of the fires and haze have been felt. ${ }^{12}$

Peat swamp forests are tropical ecosystems where saturated soils or frequent flooding prevents dead leaves and wood from fully decomposing. As this organic material slowly accumulates, it retains more water, becoming a giant sponge that holds in the moisture. Peat swamps eventually form a dome of wet organic material or "peat". The most vulnerable "deep peat" areas are over 4 meters (13 feet) deep, with depths of up to 20 meters (65 feet) in some places. As long as peat remains wet, it cannot burn. However, when peat-lands are drained in order to convert the land for agricultural production, they become susceptible to fire. Once fire starts on peat, it is difficult to extinguish due to its depth and it can smolder under the surface for months. ${ }^{13}$

\footnotetext{
${ }^{11}$ Gunardi, Ronnie and K. Martono, supra note 1.

12FEATURE STORY: Indonesia's Fire Haze Crisis., https://www.worldbank.org/en/news/feature/2015/12/01/indonesias-fire-and-haze-crisis, November 25, 2015, Accessed on 10 July 2019.

${ }^{13} \mathrm{Ibid}$.
} 


\section{Legal Ground}

7 he legal ground of study consisting of Indonesian Constitution Law of 1945, Act Number

15 Year 1990, Act Number 23 Year 1997, Act Number 22 Year 1999, Act Number 41 Year 1999, Act Number 1 Year 2009, Act Number 6 Year 1994 and Act Number 17 Year 2004 as follows:

\section{Impact of an Indonesian's Forest Fires}

\section{a. Indonesian Constitution Law of $\mathbf{1 9 4 5}$}

Indonesian Constitution Law of 1945 provides that a good and healthy environmental shall be come the fundamental right to every citizen of Indonesia, it is the reason the economic development shall be organized based on the principles of sustainable and environmentally-friendly development. The environmental quality that is currently declining and has threatened the survival of human life and other living things and there is need of protection and environmental management on serious and consistent basis by all the stakeholders. In order to ensure the legal certainty and the protection of the right of every person to earn a goods and healthy living environmental as part of the overall protection of the ecosystem, it shall be necessary to issued an Act to enhance public welfares and achieve happiness of life based on the Pancasila philosophy, and implement environmentally sustainability development guided by an integrated and comprehensive national policy which take into account the needs of present as well as future generation ${ }^{14}$

\section{b. Act Number 5 Year 1990}

Act No.5 Year 1990 concerning Conservation of Living Resources and Their Ecosystem provides among others general provisions, protection of life support systems, preservation of plant and animal species diversity including their ecosystems, sanctuary reserves, preservation of plant and animal species, sustainable utilization of living resources and their ecosystems, nature conservation area, wild species utilization, citizen participation, executive delegations of duty and task assistance, investigation, provision of criminal punishment, transitional provisions, concluding provisions. With regard to violations found in Article 40. It provides that whose ever intentionally violates the prohibited from doing any activity which leads to a change of natural integrity of sanctuary reserve and any person prohibited activities which may modify the natural integrity of the National Park's Core Zone shall be responsible to punishment by

\footnotetext{
14 Article 33 of the Constitutional Law of 1945.
} 
The Law of Forest in Indonesia: Prevention and Suppression of Forest Fires

imprisonment up to a maximum of 10 years and a fine up to a maximum of IDR 200.000.000. Paragraph 2 Article 40 provides that whoso ever intentionally violates the prohibited to catch, injure, keep, possess, care for, transport, and trade in a protected animal in live condition; keep, possess, care for, transport, and trade in a protected animal in dead condition; transfer a protected animal from one place to another, within or outside Indonesia; trade, keep or possess skin, bodies or other parts of a protected animal, or goods made of parts of the animal, or transfer from one place in Indonesia to another, within or outside Indonesia; take, destroy, exterminate, trade, keep or possess an egg and/or nest of a protected animal shall be responsible/liable to punishment by imprisonment up to a maximum of 5 years and a fine up to a maximum IDR 100.000.000,00 (one hundred million).

\section{c. Act Number 22 Year 1999}

Act No.22 Year 1999 concerning Regional Administrations provides among others general provisions; regional division; establishment and structure of a region; regional authority; form and structure of regional administration include general, DPRD, secretariat of DPRD, regional heads, obligations of a regional head, prohibition to regional heads, discharge of a regional head, act of investigation into a regional head, deputy regional head, financial position of regional head dan deputy head of region, regional apparatuses; regional regulations and decisions of regional heads; regional civil service; regional finance; cooperation and settlement of disputes; urban areas; villages includes establishment, abolition and/or merging of villages, rural government, rural representative agency, other institution, village finance, inter-village cooperation; fostering and supervisions; regional autonomy advisory council; miscellany; transitional provisions and closing provisions.

\section{d. Act Number 41 Year 1999.}

Act No.41 Year 1999 concerning Forestry, provides among others general provisions includes principles and objectives, forest control; forest status and function; forest administration; forestry planning includes general, forest inventory, forest area stipulation, forest area utilization, establishment of forest management area, preparation of forestry plans; forest management includes general, organizing forest administration and preparation of management plan, forest utilization and use of forest area, forest rehabilitation and reclamation, forest preservation and natural conservation; research and development, education and training and as well as counseling on training forestry 
includes forestry research and development, forestry education and training, forestry counseling, funding and infrastructure; supervision; delegation of authority; customary law community; community participation; class action; settlement of forestry disputes; investigation; criminal provisions; compensation and administrative sanction; transition provisions and closing provisions. With regards to legal provisions there are several sanction such as public law relating to criminal sanction, compensation, administrative sanction.

\section{e. Act Number 1 Year 2009}

Act No.1 Year 200915 concerning Civil Aviation. It provides among others general provisions, foundations/bases and objective, scope of law validity, supervisions, aircraft design and production, registration and nationality of aircraft, aircraft airworthiness and operation, air transportation, airport, flight navigation, aviation security, investigation and follow-on investigation in aircraft accident, empowerment of aviation industry and technology development, aviation information system, human resources, public participation, criminal investigation, criminal provisions, transition provisions and closing provisions. With regard to environmental preservation found in article 260. It provides that the airport business entity or airport operation unit shall be obligated to maintain noise threshold limit and environmental contamination at the airport(s) and surrounding areas in accord with threshold limit and standard quality determined by the government. In order to maintain the noise threshold limit and environmental contamination, air the airport business entity or airport operation unit may limit the time and frequency or decline aircraft operation. In addition to, in order to maintain the noise threshold and environmental contamination, the airport entity or airport operation unit shall be obligated to implement environmental management and monitoring. In this regard no mentioned about forest environmental.

\section{f. Act Number 6 Year 1994}

On 5 June 1992, Indonesia signed the United Nations Framework Convention on Climate Change (UNFCC) to prevent the anthropogenic gas concentration in the atmosphere exceeding a level that would endanger the existence of life on the earth, taking into consideration that global warming is a real threat to human welfare. For the purpose to implement such UNFCC, the President of the Republic of Indonesian (ROI) issued Act

\footnotetext{
${ }^{15}$ Act concerning Civil Aviation, supra note 8.
} 
The Law of Forest in Indonesia: Prevention and Suppression of Forest Fires

Number 6 Year 1994. ${ }^{16}$ It stipulates the right and obligation of the State. One of the obligation is to communicate actions taken to mitigate climate change. For that reason, the Minister of Environmental (MOE) established the National Committee on Climate Change (NCCC).

\section{g. Act Number 17 Year 2004}

Indonesia ratified the United Nations Framework Convention on Climate Change (UNFCCC) on 13 July 2004 and come into force on 3 December 2005, consequently Indonesia has rights and obligation to comply UNFCCC. It provides among others, the prevention of anthropogenic gas concentration in the atmosphere exceeding a level that would endanger the existence of life on the earth.

\section{Impact of an Indonesian's Forest Fires}

$\mathrm{F}$ orest fires and the resulting haze have caused significant economic; health; human life; human suffering and social costs; air transport and tourism industry, environmental such as plants, animals, insects, tigers, orangutan and elephants; and international trade as follows:

\section{a. Economic}

In the Year 2015, forest fires was increasing significantly in Indonesia. The mineral and peat fire in 2015 burnt 2.6 million hectares, especially in the provinces of Riau, Jambi, Central and West Kalimantan, Papua Island. In 2015, the World Bank (WB) estimated costs USD16.1 billion. Although only 30\% of the fire was on peatland area, it had a much higher impact than that on mineral land because of its fire density. Forest fires are caused by human both individually or collectively. ${ }^{17}$

Open burning in plantations and forest fires in Sumatra and Kalimantan have also generate thick clouds of smog across the Strait of Malacca to Malaysia, disrupting commercial flights. The haze disrupted operation, at least 16 airports. The haze imposes huge cost on the affect airlines, airports and the economies of Indonesia. It happens when owners of oil palm plantations and timber contractors carry out open burning of the discards of their harvest. The lack of fire-suppression system in the forest and plantations and the sheer size of the areas compound the problems. The total economic costs of the forest fires of 2015 exceed US\$ 16 billion. Such costs include losses to agriculture, forestry, transport, international trade, industry, tourism and other sectors.

\footnotetext{
${ }^{16}$ Act Concerning Undang-Undang tentang Pengesahan Konvensi Kerangka Kerja PBB tentang Perubahan Iklim (Ratification of United Nations Framework Convention on Climate Change (Act No.6 Year 1994 (June 5th, 1994).

17 https://www.cifor.org/library/6357/.
} 
Early estimates of the total economic costs of the forest fires in 2015 in Indonesia alone exceed US $\$ 16$ billion. This is equal to about 1.8\% of Indonesia's Gross Domestic Product (GDP). This estimate includes losses to agriculture, forestry, transport, trade, industry, tourism, and other sectors. Some of these costs are direct damage and losses to crops, forests, houses and infrastructure, as well as the cost of responding to the fires. Many of the economic losses result from the disruption of air, land and sea travel due to the haze. These damages and losses are expected to have serious impact on the economic growth rate of affected provinces and the government's efforts to reduce poverty in the hardest-hit regions, such as Central Kalimantan. ${ }^{18}$

\section{b. Health}

The effects of the forest fires were felt in Brunei, Singapore, Malaysia, Thailand and Viet Nam as well. The forest fires caused at least US\$ 4.5 billion in damage in the region. Most of these costs were attributed to the health consequences of the forest fires due to the haze was the heaviest and persisted the longest over parts of Indonesia, several studies have concluded that the Indonesian populations suffered the greatest health costs. The smoke on daily mortality in Kuala Lumpur reported an increase in mortality for 65 -to 74 years old that lasted several weeks. ${ }^{19}$

Local airports such as in Jambi, Pekanbaru, Palembang, South Sumatra, Palangkaraya, (Central Kalimantan), Indonesia, the cancellation of commercial flight very often caused by forest fires. It was reported that in parts of Malaysia an unhealthy air quality was recorded. Such forest fires damage the environment on the resources and forest-rich islands of Sumatra, Kalimantan as farmers clear plantation and forest lands. There were slash and burn practice is common on these islands and form a recurring problem, especially in the dry season. The El Nino weather phenomenon could cause an extended dry season in Indonesia, implying a higher risk of forest fires in Southeast Asia's largest economy.

\section{c. Human Life}

The human contributions to greenhouse gas emissions are estimated 1,354 million tons of $\mathrm{CO} 2$ have been released into the atmosphere from the burning of 2 million hectares of forest fires in Sumatra and Kalimantan. The pollution from forest fires has been appalling. People are dying from respiratory problems and day-to-day life is

\footnotetext{
${ }^{18}$ FEATURE STORY, supra note 13.

${ }^{19}$ Elizabeth Frankenberg, Douglas Mc Kee and Duncan Thomas., Health Consequences of Forest Fires in Indonesia. https://www.jstor.org/stable/1515179; Demography, Vol.42 (1) Feb.2005, pp 109-129 Accessed: 17 May 2019.
} 
affected, with the closure of schools and people wearing masks to protect their health. Sumatra and Kalimantan are blessed with peatlands that are rich in organic materials. These peatlands water catchment areas prevent flooding during heavy rains and maintain humidity during droughts. In order to clear this land the perpetrators, have chosen the cheapest and easiest option by setting fire to them. ${ }^{20}$

In addition to, the forest fires also have a negative impact on agricultural systems. Agricultural crops require 3 key things such as fertile soil, water, and a good amount of sunlight. If anyone couple these with good agricultural practice and land management then anyone can preserve the sustainability of the crop for many years to come. If something disrupts the system, then anyone can expect to witness huge drops in productivity and/or quality. More than 100 million people will be in poverty by 2030 if no universally tackle climate change. The impacts of climate change will be huge. Many poor people will be suffering from more harvest failure caused by flooding, droughts, anomalies of weather patterns and increases in temperature. ${ }^{21}$

\section{d. Human Suffering and Social Costs}

Air quality during high burning periods in villages near the fires regularly exceed the maximum level of 1000 on the international Pollutant Standard Index (PSI). The toxic smoke causes widespread respiratory, eye, and skin ailments and is especially hazardous for the very young and the elderly. The toxic air they breathe include carbon dioxide, cyanide, and ammonium. The long-term health impacts are not yet known but are expected to be highly significant. With to social cost, schools across the region close due to the haze, crippling many low-income families and prompting them to fall back into poverty. Approximately 5 million students have been impacted by school closures in 2015. 22

\section{e. Air transport and Tourism Industry}

Indonesia's economy took a US\$16bn hit in 2015 from forest fires that cloaked south-east Asia in haze, more than double the sum spent on rebuilding Aceh after the 2004 tsunami. The fires and resulting haze are an annual occurrence caused by slash-andburn land clearance. But the blazes in 2015 were the worst for some years, causing air

\footnotetext{
${ }^{20}$ Nelia Latief., The Impact of Indonesia's Forest Fires, Posted 01/12/2015.

http://www.ethicalteapartnership.org/the-impact-of-indonesias-forest-fires/. Accessed on 18 May 2019.

${ }^{21}$ Ibid.

22FEATURE STORY, supra note 13.
} 
quality to worsen dramatically and many to fall ill across the region. In a quarterly update on the Indonesian economy, the fires had devastated 2.6 million hectares of forest and farmland across the archipelago from June to October 2015.23

The cost to south-east Asia's biggest economy is estimated at US\$16.1bn, equivalent to $1.9 \%$ of predicted GDP in 2015. In contrast, it cost US\$7bn to rebuild Indonesia's westernmost province of Aceh after it was engulfed in 2004 by a quake-triggered tsunami, with the loss of tens of thousands of lives. The economic impact of the fires has been immense. Fire has long been a popular way of quickly and cheaply clearing land on Indonesia's Sumatra Island and Kalimantan, to make way for lucrative palm oil plantations. But the fires burn out of control and produce noxious haze during the months-long dry season, particularly when started on carbon-rich peatland. ${ }^{24}$

If every hectare burned in 2015 were converted to palm oil, the value would be about US\$8bn. Indonesia is the world's biggest producer of the oil, used in numerous everyday goods from biscuits to shampoo. On the one hand 16 billion dollars cost to the public, on the other hand, eight billion dollars to a handful of individuals. The estimated costs are based on an analysis of the types of land burned and take into account the impact on agriculture, forestry, trade, tourism and transportation, as well as short-term effects of the haze such as school closures and on health. More than half a million people suffered acute respiratory infections in Indonesia, while many in neighboring Singapore and Malaysia also fell ill. ${ }^{25}$

\section{f. Environmental such as plants, animals, insects, tigers, orangutan and elephants.}

More than 2.6 million hectares of forest, peat, and other land have burned in 2015. Burned peat areas can be restored, but short-term impact includes the loss of timber and non-timber forest products, and the loss of habitat for pollinators, wildlife, and grazing lands. While not yet fully analyzed, the costs related to biodiversity may exceed US \$295 million for 2015. The long-term impact on wildlife and biodiversity is also not fully known, but thousands of hectares of habitat for orangutans and other endangered species have been destroyed. ${ }^{26}$

\footnotetext{
${ }^{23}$ Indonesia Forest Fires Cost Twice as Much as Tsunami Clean-up, says World Bank https://www.theguardian.com/environment/2015/dec/15/indonesia-forest-fires-cost-twice-as-much-astsunami-clean-up-says-world-bank. Accessed on 10 July 2019

24 Ibid.

${ }^{25} \mathrm{Ibid}$.

${ }^{26}$ FEATURE STORY:., supra note 13.
} 
Fires raging across Indonesia over the last three months have claimed more than 2 million hectares of rainforest and peatland. Fires take place annually season is the worst on record and unlike natural wildfires that got out of hand elsewhere, these are entirely manmade. Most of the fires were started during "slash and burn" of rainforest to make way for palm oil agriculture. Meanwhile, canals dug to drain the moist, swampy land so it can be farmed have lowered the water table and drained the peat. Much of Indonesia's rainforest grows on top of peat-land made up of decomposing plant matter that has built up over thousands of years. After the trees have been cut down and the land drained, the dry, exposed peat fuels remnant flames, releasing stored carbon into the atmosphere. Ongoing deforestation over past decades has made Indonesia among the biggest emitters of carbon dioxide in the world. ${ }^{27}$

A haze of fine particulates and hazardous gases hangs heavy over the country. In Indonesia, around half a million people have been struck by acute respiratory infections, and at least 10 have died. They are demanding a government response because this is a humanitarian crisis. The haze can also have a devastating impact on plants and animals. The last time fires happened on anything close to this scale insect species were killed off and bees were unable to navigate, with a damaging domino effect on plants that rely insects for pollination. The fires are also raging in virgin forest and national parks, threatening species already at risk of extinction. These include the fewer than 400 remaining Sumatran tigers, the Bornean orangutan, and the Sumatran rhino, which is down to less than 100 surviving animals. Deforestation is already a major threat to these endangered animals, and now the fires have put them at even greater risk. In some areas, elephants were becoming disoriented by the haze and wandering into residential areas where they risk being killed.28

\section{g. International Trade}

The issues concerning trade and the environment, especially forest fires, continue to be important and to receive widespread attention. Concerns about environmental issues are now being taken more seriously than previously, taking into consideration that an increasing attention is paid to the issues of international trade and environment. It is becoming more apparent that the interactions between the two or more countries are complex and varied, and in most cases, not easily explained or understood. Indonesia is

\footnotetext{
27 Indonesia's forest fires: An environmental disaster of global proportions. https:/ / www.dw.com/en/indonesias-forestfires-an-environmental-disaster-of-global-proportions/a-18828623-0,Accessed on 10 July 2019. 
biologically, culturally, and geographically diverse and unique, arid controls a wealth of natural resources, particularly oil, gas, and timber. ${ }^{29}$

Indonesia exports a range of forest products a variety of nations around the world. The United States, Japan, Singapore are the primary importers of Indonesian products, trade in forest products with other ASEAN countries has been growing, in large part due to China's increasing demand for goods. Japan is by far Indonesia's single most important trading partner, the highest percentage for any of the countries with which Indonesia shares a market. The United States follows Japan as the second most important international trade partner. Japan, the USA and Singapore therefore account for over $47 \%$ of Indonesian exports, and while this represents a range of goods, not only forest products, the power of these markets must be considered in relation to the effect of international trade policy on Indonesia's forests. 30

\section{Legal Preventing of Forest Fires}

7 he legal prevention of forest fires includes the government level action, the local government level action and the private enterprises level action as follows:

a. The Government Level Action

Ahead of ASEAN Games of August 2018, Indonesian fights forest fires. The satellite readings showed the 29 hot spots were in four regencies and municipalities in Riau, South Sumatra. The most-hot spots, 15 (fifteen), were detected in Dumai, whilst another 7 (seven) were in Rokan Hilir regency, 6 (six) in Bengkalis and 1 (one) in Siak. The government of the ROI responded by sending helicopters to extinguish the fires. ${ }^{31}$

Following a spell of unhealthy air in forest fires hotspots near Palembang, the Indonesian government of ROI ramps up efforts to clear it up before the games. Authorities are looking into the possibility of cloud seeding to combat the hotspots. Cloud seeding is a form of weather modification that changes the amount or type of precipitation that falls from clouds, by shooting flares of salt into suitable clouds. ${ }^{32}$ The implementation of Weather Modification Technology (WMT) to secure the $18^{\text {th }}$ AG from

\footnotetext{
${ }^{29}$ Joshua Brann., Trade Policy in Indonesia Implications for Deforestation. http://www.saisjournal.org/posts/tradepolicy-in-indonesia. Access ed on 18 May 2019.

${ }^{30}$ Ibid.

31 Indonesia fights forest fires ahead of Asian Games next month; https:/ / www.straitstimes.com/asia/se-asia/indonesiafights-forest-fires-ahead-of-asian-games-next-month

${ }^{32}$ Laineyh Loh., How Indonesia is Gearing up for the 2018 Asian Games;

https:/ / travelwireasia.com/2018/07/how-indonesia-is-gearing-up-for-the-2018-asian-games /
} 
The Law of Forest in Indonesia: Prevention and Suppression of Forest Fires

haze coming from forest fires. WMT increases rainfall and ensure that the haze originating from forest fires does not reach the $18^{\text {th }}$ AG venues. The decision to extend the implementation of WMT was made following a weather forecast released by the Meteorology, Climatology and Geophysics Agency, which indicates that hot weather in Palembang continues up to 15 days ahead, taking into account that August-September 2018 was the peak of the dry season, a condition critical for the organization of the $18^{\text {th }}$ AG, which commences from Aug. 18 to Sept. 2, 2018.33

Twenty hot spots were identified in South Sumatra's regions. The air patrols had found land fires in Tulung Selapan Ilir area and Cinta Jaya sub-district in Ogan Komering Ilir. The fires have been extinguished, meanwhile, a joint ground task force of the BNPB's South Sumatra chapter, the Environment and Forestry Ministry's Manggala Agni forest and land fires task force, and combined personnel of the Indonesian Military and the National Police were involved in the dissemination of fire prevention and early fire extinguishing techniques in the province. ${ }^{34}$

\section{b. Local Government Level Action}

The government educates locals residents on how to utilize the land so that they do not burn the forest anymore, especially forest fires in Palangkaraya, the Central Kalimantan Province's capital city, South Sumatra and Riau provinces that were vulnerable to forest fires, because they had a significant amount of peat land. In addition to, the Technology Assessment and Application Agency also participates to prevent forest fires in South Sumatra and Riau provinces as follows. 35

The Palangkaraya Health Office (PRHO) has taken precautionary measures to anticipate unexpected eventualities by ensuring the readiness of health centers and the availability of medicines. As part of the precautionary measures, health workers distributed face masks to the city's firefighters, while the city's health workers are also preparing to help residents affected by smog. At the moment, none of the residents is suffering from health problems due to the impact of the smog. Over these past few days, bush and forest fires have been spotted in certain areas around the city. On July 2, 2019, a thin cloud of smog blanketed the city's sky. The Environment and Forestry Ministry's

\footnotetext{
${ }^{33}$ Martha Herlinawati S., PNPB Extends Weather Modifications For the $18^{\text {th }}$ AG.

${ }^{34}$ AG Media Publication in cooperation with The Jakarta Post.

${ }^{35}$ Eliswan Azly,Editor: Bambang Purwanto., Indonesia makes serious effort to tackle forest fires. https://en.antaranews.com/news/128420/indonesia-makes-serious-effort-to-tackle-forest-fires, accessed on 11 July 2019, COPYRIGHT (C) ANTARA 2019.
} 
Acting Director for Forest and Land Fire Control is trying to change their paradigm and culture of burning forests but it will take much more time and effort. The authorities in Palangkaraya have been striving to halt the recurrence of bush and forest fires in the Central Kalimantan Province's capital city amid the dry season, while the city's health workers are also preparing to help residents affected by smog. ${ }^{36}$

In South Sumatra Province, Indonesian military personnel have been included in the joint efforts to halt recurrences of land by regularly conducting public awareness campaigns in Banyuasin, Ogan Komering Ilir. Precautionary measures were also taken by monitoring vulnerable areas. In this regard, the South Sumatra police has warned plantation companies and farmers in the province to avoid slash-and-burn farming methods. The community members and plantation companies found conducting burn farming methods will be punished. The smog does not harm the health of the local people but is a problem for neighboring countries because it potentially threatens their people's health and aviation activities. The owners of gutted farmlands potentially gutted should remain cautious. They have been asked to build canal blockings, and prepare water storage facilities and keep fire extinguishers handy. ${ }^{37}$

In South Sumatra and Riau provinces Technology Assessment and Aplication Agency also participated in weather modification technology, to overcome drought and forest and land fires in the Riau region. The Technology Assessment and Aplication Agency is using weather modification technology for forest fires in Riau and received requests from regions such as South Sumatra to use the same technology to stimulate rain. Technology Assessment and Aplication Agency spends around IDR50 billion annually to use the technology and adding that when demand increases and can spend IDR70 billion to IDR80 billion from technology users to make weather modifications. In addition to using the technology to stimulate the acceleration of the process of rain, Technology Assessment and Aplication Agency also helps efforts to wet peat-lands to reduce the risk of fire. ${ }^{38}$

\section{c. Private Enterprises Level Action}

Asia Pulp \& Paper Sinar Mas (APP Sinar Mas) as private enterprise also participate to fight forest fires. In this regards APP Sinar Mas have two main strategies of forest fires fighting such as prevention and mitigation to implement by increasing the accuracy of

\footnotetext{
36 Ibid.

37 Ibid.

${ }^{38} . \mathrm{Ibid}$.
} 
mapping efforts for the three places considered vulnerable to fires such as in Ogan Komering Ilir, Banyuasin and Musi Banyuasin. Fire detection operations have been doubled to increase the effectiveness of risk mitigation efforts. In addition to, the company continues to play an active role in helping prevent and mitigate forest fires, both inside and outside of its concession zone. The company committed to provide the best contribution for the nation. In addition to, the company is also working together with authorities and other key stakeholders to prevent forest fires in its areas of operations, as part of APP Sinar Mas' commitment to protecting forests in its Forest Conservation Policy. ${ }^{39}$

APP Sinar Mas also deployed Super Puma helicopters, which can carry up to 4,000 liters of water, for aerial firefighting operations to suppress forest fires in Ogan Komering Ilir regency, South Sumatra, to help ensure that the $18^{\text {th }}$ AG proceed without concerns about spectators suffering from the effects of nearby forest fires. Additionally, APP Sinar Mas puts up intensive efforts to help fight forest fires in Ogan Komering Ilir regency. Such effort is part of APP Sinar Mas's desire to support President Joko Jokowi's desire to see "no fire and haze" in the days leading up to and throughout the running of the $18^{\text {th }}$ AG.

APP Sinar Mas lends its best support to help the $18^{\text {th }}$ AG become a successful event free from fires and haze. Its commitment does not end at just protecting the concession areas of their partners from forest fires. APP Sinar Mas have also prepared measures to deal with such disasters outside of their concessions in South Sumatra and have provided aid in the form of Super Puma helicopters with 4,000 liters of water-carrying capacity for water-bombing operations to extinguish fires in Ogan Komering Ilir, some 30 to 40 kilometers away from APP Sinar Mas' concession zone. This is being done to help prevent fires from spreading and harming local residents and causing problems for the 18th AG. 40

For the purpose of firefighting operation, APP Sinar Mas allocates IDR 50 billion, in additional funds outside of its annual budget to fight forest fires and haze in the period leading up to and encompassing the $18^{\text {th }}$ AG. In total, APP Sinar Mas invested more than IDR 170 billion in South Sumatra that year (2018). Such company's investment for preventing forest fires and haze in South Sumatra has been allocated toward the goals such as educating local communities around the concession zone to give them a better

\footnotetext{
${ }^{39}$ APP Sinar Mas combats forest fires to support Asian Games 2018. http:/ / www.thejakartapost.com/adv/2018/07/20/app-sinar-mas-combats-forest-fires-to-support-asian-games201.html. 
sense of understanding on the subject of forest fires; building 13 new fire lookout towers 32 meters in height, each with a lookout radius of 10 kilometers. The company has a total of 16 of these fire lookout towers; building 25 new lookout posts with mini-towers 12 meters in height. The company has a total of 52 of these posts; preparing firefighting teams that can be deployed around the clock and adding as many as 460 new members, in addition to the current 2,700 APP Sinar Mas personnel in charge of fire extinguishing operations; buying four helicopters; procurement of 41 fire-extinguishing special forces; and various fire-extinguishing equipment, such as airboats and tank trucks. ${ }^{41}$

In line with APP Sinar Mas, Riau Andalan Pulp and Paper (RAPP) also join to fight forest fires. Since January 31, 2016, RAPP set up the program Fire-Free Village Program (FFVP) to local officials. It is supporting the $18^{\text {th }}$ AG by raising awareness on the dangers and impacts of forest fires in an effort to reduce the number of forest fires in Riau. Through its FFVP, RAPP educates villagers living in and near the company's concession areas about the dangers of the slash-and-burn method, which farmers commonly use to clear land for cultivation. The program was part of the company's support to the $18^{\text {th }} \mathrm{AG}$, taking into account that Indonesia is hosting Asiad from Aug. 18 to Sept. 2, 2018 in Palembang, 27 villages in five districts of Pangkalan Kerinci, Riau, have been involved in the program since it was implemented in 2014. The FFVP provides agricultural assistance like tree seedlings, facilities and infrastructure, as well as training on alternative land clearing methods. It cooperated with local branches of religious organizations such as the Indonesian Ulema Council and local environmental NGOs like the Laskar Alam Foundation and Perkumpulan Tapak in preventing forest fires. The program claims to have successfully reduced forest fires incidents in Pangkalan Kerinci, from $0.18 \%$ of burned areas in 2014 to $0.03 \%$ of burned areas in 2017.42

\section{Legal Suppression of Forest Fires}

7 he legal suppression of forest fires includes legal liability, legal responsibility of violation and administrative sanction as follows.

\section{a. Legal Liability}

On 2 January 2019, the Supreme Court upholds IDR 1 Trillion (US\$69 million) decision against company for damage caused by forest fires. Such decision is a lower

\footnotetext{
${ }^{41} \mathrm{Ibid}$.

${ }^{42}$ News Desk, The Jakarta Post., Jakarta Generates up to 2,400 Tons of Plastic Waste Daily; http://www.thejakartapost.com/news/2018/08/09/several-airlines-seek-extra-flights-during-asian-games.html
} 
The Law of Forest in Indonesia: Prevention and Suppression of Forest Fires

court verdict ordering PT National Sago Prima (NSP) to pay IDR 1 trillion (US\$69 million) in fines for causing forest fires in Riau in 2015. Such lawsuit against NSP was filed by Indonesia's Ministry of Environment and Forestry to the South Jakarta District Court in 2016. Ministry of Environmenal and Forestry presented evidence that the 2015 fires had originated from lands owned and managed by NSP. The court found that the forest fires has been caused by NSP's negligence and ordered the company to pay fines recover the cost of rehabilitating the approximately 3,000 hectares in the Riau Island affected by the fires. ${ }^{43}$

NSP appealed the decision to the Jakarta High Court and the Supreme Court. The IDR 1 trillion fine is the largest ever imposed on a plantation company for environmental damages and the ruling offers legal precedence for other environmental damage cases filed against similar companies, especially palm oil companies that have been blamed for numerous widespread and highly destructive forest fires in Indonesia. Such lawsuit purported to protect the interests of the people who have been greatly disadvantaged by these forest fires, taking into consideration, there were a lot of losses ranging from health effects, airports that were closed to people's economic losses. ${ }^{44}$

\section{b. Legal Responsibility of Violation}

For the purpose to suppress the violation of regulations, the government of ROI has punished 23 companies for causing forest fires that spread thick, smoky haze around Southeast Asia, 33 more companies are under scrutiny and waiting for decisions on possible punishment. There are total of 56 companies were involved in the land-clearing activities that led to the forest fires. Mostly pulp wood and palm oil plantations operating on Sumatra and Kalimantan Islands, have received punishments ranging from administrative sanctions to revocation of licenses. Three companies shut down as their licenses were revoked, whilst the rest licenses of 16 were suspended and four companies were placed under close observation. The government does not hesitate to take stern legal actions against companies found violating the law and considering the kinds of sentences for the remaining 33 companies. In addition to, the police were processing 301 cases of

${ }^{43}$ Coconuts Jakarta., Supreme Court upholds $\$ 69$ Million Fine Against Palm Oil Company Over negligence that Caused Forest Fires. Published on: 4 January 2019.

https://www.business-humanrights.org/en/indonesia-supreme-court-upholds-69-million-fine-against-palmoil-company-over-negligence-that-caused-forest-fires.Accessed on 19 May 2019.

${ }^{44} \mathrm{Ibid}$. 
forest fires set by individuals and corporations, with three of them having been handed to the Attorney General's Office for further legal proceedings. ${ }^{45}$

Article 78 paragraph (1) of Act No.41 Year 1999 provides that any person intentionally destroying the infrastructure and facilities of forest protection or any person receiving business license for forest area utilization, environmental services utilization, timber and non-timber forest product utilization, and non-timber forest product collection, shall be subject to maximum imprisonment of 10 (ten) years and maximum fine of IDR 5.000.000.000 (five billion rupiah). In addition to, each holder of business license for forest area utilization, utilization of environmental services, forest products utilization, forest products collection, who violates the provision of criminal provision in Article 78 of Act No.41 Year 1999 shall be subject to administration sanction and to pay compensation to the State in accordance intensity of damages or effects thereof, with the costs of rehabilitation, forest recovery or other necessary actions.

\section{Suppression of Forest Fires Used an Aircraft Operations}

n Indonesian forest fires in 1997 had generated around 600 million tons of GHG Lemission. The haze crisis could become the worst one recorded in the region. For the purpose to suppress the haze as a result of forest fires from Indonesia, several States such as Australia, Canada, Malaysia, Singapore and Russia send an aircraft's bombing water as follows:

a. Australia and Canada

On 12 October 2015, Australia sent L-100 Hercules aircraft to Sumatra Island. Such aircraft operates for five days in South Sumatra and on 15 October 2015 Australia sent Lockheed L 100-30 Hercules air aircraft and landed in Sultan Mahmud Badaruddin II airport before being deployed to extinguish forest fires, ${ }^{46}$ whilst Canada sent Canadianmade CL-215 amphibious aircraft to suppress the forest fires in Kalimantan and Sumatra Islands. Such aircraft can fly then land on a river, take or sea to scoop up a very large amount water and then take-off again to douse fires an area of between 1 ha to 1.6 ha. So, with just one-strike fires are gone. ${ }^{47}$

\footnotetext{
${ }^{45}$ The Jakarta Post., supra note 2. https://www.thejakartapost.com/news/2015/12/23/indonesia-punishes-23companies-causing-forest-fires.html. December 23, 2015.Accessed on 19 May 2019.

${ }^{46}$ Gunawan Djajaputra Ahmad Redi., The Civil Aviation, Climate Change Reduction and Legal Aspects of Forest Fires in Indonesia. Vol.9\&7) IOSR-JAC 11 (July 2016); See Also Gunardi, Ronnie and Dr Martono., supra note 1.

${ }^{47}$ Wahyudi Soeriaatmadja Indonesian Correspondent in Jakarta and Shamon Teoh Malaysia Correspondent in Kuala Lumpur, on 5 October 2015.
} 


\section{b. Malaysia and Singapore}

For the purpose to suppress the forest fires in Indonesia, Malaysia dispatches one Bombardier amphibious aircraft, one Hercules C-130 aircraft and a survey helicopter. The bombardier amphibious aircraft uses a "water bombing" technique capable of putting out a fire the size of a football field. Another C-130 from Malaysia's Airforce Agency (MMEA) operated seven hours a day to put out the forest fires burning up large swathes of forest in South Sumatra and C-130 from MMEA ferrying logistic to South Sumatra where the 25-member team be stationed for a week. The week-long operation is expected to cost up to 1.7 million ringgit or more US\$400,000, whilst Singapore sent a C-130 aircraft for cloudseeding and Chinook Helicopter equipped with a water bucket for aerial fire-fighting, however fire-fighting helicopters were unable to water-bomb certain areas due to very low visibility. 48

\section{c. Russia}

For the purpose to suppress the forest fires in Indonesia, Russia is also sending two amphibious water-bombing aircraft. The Russian-made aircraft the Beriev Be-200s were scheduled to arrive in Palembang, South Sumatra. The plane capable to scoop 12,000 liters of water from rivers, lakes or the sea and dump it over the forest fires. The Russian-made Beriev-200 water bombers were involved one of them had arrived on 21 October 2015. Such aircraft carry out up to $37,200 \mathrm{~kg}$ of water and fly up to 3,850 km without refueling. ${ }^{49}$

\section{CONCLUSION}

$\mathrm{B}^{\mathrm{a}}$ ased on the study above-mentioned the authors conclude that the government has issued several laws and regulations, ratified international convention, local government as well as famers, the forestry-concession owners, foreign as well domestic aircraft has been used to suppress such forest fires, but in the fact that permanent forest fires increasingly each year. With regard to the laws and regulations, the authors finds that it is enough to prevent the forest fires, but the implementation of laws, regulation, socialization and execution of court decision should be increase to prevent and suppress the forest fires. Some local authorities such as governor, district authorities and others not yet seriously to response the forest fires, especially for permanent forest fires. It is recommended that all the government, local government, legal

\footnotetext{
48 Gunawan Djajaputra, Ahmad Redi., supra note 48.

${ }^{49}$ Gunardi, Ronnie and Dr Martono., supra note 1.
} 
institution, individual as well corporate should together provide some action to prevent and suppress such forest fires taking into account the significant impact of the forest fires.

\section{BIBLIOGRAPHY}

\section{Articles}

Gunardi, Ronnie and K.Martono, 2017. Legal Aspects, Economic and Aircraft's Water Bombing Related to Forest Fires in Indonesia.www.ijbmi.org, Vol. 6 (3);

Gunawan Djajaputra, Ahmad Redi., 2016. The Civil Aviation, Climate Change Reduction and Legal Aspects of Forest Fires in Indonesia. IOSR-JAC 11, Vol.9\&7.

\section{Documents}

Act Concerning Conservation of Living Resources and Their Ecosystems, Act.No.5 Year 1990, State Gazette of the Republic of Indonesia Number 49 Year 1990, Supplement State Gazette of the Republic of Indonesia Number 3419);

Act Concerning ratification of the United Nations Framework Convention on Climate Change (UNFCCC), Act No.6 Year 1994;

Act Concerning Undang-Undang tentang Pengesahan Konvensi Kerangka Kerja PBB tentang Perubahan Iklim (Ratification of United Nations Framework Convention on Climate Change (Act No.6 Year 1994 (June 5th, 1994);

Act Concerning Environmental Management, Act.No.23 Year 1997, State Gazette of the Republic of Indonesia No.68 Year 1997, Supplement State Gazette of the Republic of Indonesia Number 3699;

Act Concerning Regional Administrations, Act No.22 Year 1999, State Gazette of the Republic of Indonesian Number..., Supplement State Gazette of the Republic of Indonesian No....; Act concerning Forestry, Act No.41 Year 1999, State Gazette of the Republic of Indonesia No.167 Year 1999, Supplement State Gazette of the Republic of Indonesian No.3888;

Act Concerning Civil Aviation, Act No.1 Year 2009, State Gazette of the Republic of Indonesia No.1 Year 2009, Supplement State Gazette of the Republic of Indonesia No.4956;

Presidential Regulation Concerning National Council for Climate Change, (Pres.Reg.No.46 Year 2008) [4 July 2008]. 
The Law of Forest in Indonesia: Prevention and Suppression of Forest Fires

\section{Others}

AG Media Publication in cooperation with The Jakarta Post;

APP Sinar Mas combats forest fires to support Asian Games 2018. http:/ / www.thejakartapost.com/adv/2018/07/20/app-sinar-mas-combats-forest-firesto-support-asian-games-201.html;

Coconuts Jakarta., Supreme Court upholds \$69 Million Fine Against Palm Oil Company Over negligence that Caused Forest Fires. Published on: 4 January 2019;

Eliswan Azly,Editor: Bambang Purwanto., Indonesia makes serious effort to tackle forest fires; https:/ / en.antaranews.com/news/128420/indonesia-makes-serious-effort-to-tackle-forestfires, accessed on 11 July 2019, COPYRIGHT @ ANTARA 2019;

Elizabeth Frankenberg, Douglas Mc Kee and Duncan Thomas., Health Consequences of Forest Fires in Indonesia. https://www.jstor.org/stable/1515179; Demography, Vol.42 (1) Feb.2005, pp 109-129 Accessed: 17 May 2019;

FEATURE STORY: Indonesia's Fire and Haze Crisis.,

https://www.worldbank.org/en/news/feature/2015/12/01/indonesias-fire-and-

haze-crisis, November 25, 2015, Accessed on 10 July 2019;

https:/ / www.business-humanrights.org/en/indonesia-supreme-court-upholds-69-million-

fine-against-palm-oil-company-over-negligence-that-caused-forest-fires.Accessed on 19 May 2019;

https://www.thejakartapost.com/news/2015/12/23/indonesia-punishes-23-companies-

causing-forest-fires.html. December 23, 2015.Accessed on 19 May 2019;

http://unfccc.int/Kyoto_protocol/status_of_ratification/items/2613.php(down load on 1

November 2016;

https://www.cifor.org/library/6357/;

Indonesia's forest fires: An environmental disaster of global proportions;

https://www.dw.com/en/indonesias-forest-fires-an-environmental-disaster-of-global-

proportions/a-18828623-0,Accessed on 10 July 2019;

Indonesia Forest Fires Cost Twice as Much as Tsunami Clean-up, says World Bank https:// www.theguardian.com/environment/2015/dec/15/indonesia-forest-fires-costtwice-as-much-as-tsunami-clean-up-says-world-bank. Accessed on 10 July 2019; Indonesia fights forest fires ahead of Asian Games next month; https://www.straitstimes.com/asia/se-asia/indonesia-fights-forest-fires-ahead-ofasian-games-next-month; 
Joshua Brann., Trade Policy in Indonesia Implications for Deforestation;

http://www.saisjournal.org/posts/trade-policy-in-indonesia. Access ed on 18 May 2019.

Laineyh Loh., How Indonesia is Gearing up for the 2018 Asian Games;

https:/ / travelwireasia.com/2018/07/how-indonesia-is-gearing-up-for-the-2018-asian-

games/;

Martha Herlinawati S., PNPB Extends Weather Modifications For the $18^{\text {th }}$ AG;

Nelia Latief., The Impact of Indonesia's Forest Fires, Posted 01/12/2015;

http://www.ethicalteapartnership.org/the-impact-of-indonesias-forest-fires/. Accessed on 18 May 2019;

News Desk, The Jakarta Post., Jakarta Generates up to 2,400 Tons of Plastic Waste Daily;

http:/ / www.thejakartapost.com/news/2018/08/09/several-airlines-seek-extra-flightsduring- asian-games.html;

The Jakarta Post., Indonesia Punishes 23 Companies for Causing Forest Fires;

Wahyudi Soeriaatmadja Indonesian Correspondent in Jakarta and Shamon Teoh Malaysia Correspondent in Kuala Lumpur, on 5 October 2015. 